\title{
POOR OUTCOMES WITH TREATMENT OF HEPATORENAL SYNDROME TYPE 1 WITH SPLANCNIC VASOCONSTRICTORS AND ALBUMIN: report of seven cases and review of the literature
}

\author{
Jamile Rosário KALIL, Liv Aparicio CERQUEIRA, Daniel Silva BARBOSA, \\ Marina Pamponet MOTTA, Marília da Silva NERY and Paulo Lisboa BITTENCOURT
}

\begin{abstract}
Context - Treatment of hepatorenal syndrome type 1 (HRS-1) with splancnic vasoconstrictors and high-dose albumin has been associated with reversal of renal failure in approximately $60 \%$ to $80 \%$ of the cases in pilot or uncontrolled studies. Objective - To evaluate the results of treatment of HRS-1 with terlipressin and high-dose albumin. Methods - All patients with HRS-1 that underwent treatment with terlipressin and high-dose albumin at our unit were retrospectively reviewed. Outcomes including reversal of renal failure and death were recorded and compared to baseline clinical and laboratory parameters. Results - Seven subjects (median age 64 [47-69] years, 5 males) with median Child-Pugh and MELD scores of 12 [10-15] and 22 [17-38], respectively, hospitalized with decompensated chronic liver disease secondary to tense ascitis and infections, who exhibited criteria for HRS-1, were submitted to therapy with terlipressin and high-dose albumin according to a predefined standard protocol. Baseline creatinine levels were $2.9[2.3-4.0] \mathrm{mg} / \mathrm{mL}$. None of the patients achieved reversal of HRS-1 and five subjects died on-treatment due to sudden-death ( $\mathrm{n}=$ 1), multiple organ dysfunction associated with end-stage liver failure $(n=2)$ and sepsis $(n=2)$. Conclusions - Treatment of HRS-1 with terlipressin and high-dose albumin was not associated with reversal of renal failure, but most of the treated subjects had severe end-stage liver disease with high MELD scores as well as high baseline creatinine values, parameters previously associated with bad outcomes.

HEADINGS - Hepatorenal syndrome. Liver diseases. Vasoconstrictor agents. Albumin.
\end{abstract}

\section{INTRODUCTION}

Hepatorenal syndrome (HRS) is defined by the development of acute renal failure, usually expressed by elevation of creatinine levels above $1.4 \mathrm{mg} / \mathrm{mL}$, in the absence of a recognizable cause in a patient with end-stage chronic liver disease $(C L D)^{(3,4,27)}$. Its diagnosis implies in the exclusion of other common causes of renal failure in cirrhotics, such as use of nephrotoxic agents, intrinsic renal diseases, particularly glomerulonephritis, renal dysfunction due bacterial infections as well as hypovolemia that do not reverse with volume expansion and antibiotics ${ }^{(3,14,15)}$. It is regarded as a functional kidney failure due to intense renal vasoconstriction usually due to worsening of the circulatory dysfunction of cirrhotics ${ }^{(26)}$, characterized by progressive splancnic and systemic vasodilation leading to a decrease in the effective plasma volume, arterial hypotension and ultimately hyponatremia and renal failure. It usually occurs in subjects with ascites and is frequently precipitated by infections, particularly spontaneous bacterial peritonitis ${ }^{(11,13,30)}$.

It is usually classified in two types, based in the magnitude and timing of the creatinine levels abnormalities. In this regard, HRS type 1 (HRS-1) is characterized by doubling of creatinine levels to a value greater than $2.5 \mathrm{mg} / \mathrm{dL}$ or by a reduction in creatinine clearance to half the baseline level to a value less than $20 \mathrm{~mL}$ per minute in a time period of 2 weeks; whereas less impressive derangements in renal function are defined as HRS type $2^{(3,27)}$.

Until recently, HRS-1 was regarded as a progressive and fatal complication of end-stage CLD, leading to death in weeks ${ }^{(14)}$, but up to now several uncontrolled studies and case reports have demonstrated reversal of HRS-1 with the use of splancnic vasoconstrictors ${ }^{(5,10)}$, including different treatment schedules of terlipressin, octreotide, somatostatine, midodrine and norepinephrine, all coupled with infusion of high-dose intravenous albumin $^{(1,2,8,9,15,18,19,21,22,23,31,24,29,33)}$. In these reports,

Unit of Gastroenterology and Hepatology of the "Hospital Português", Salvador, BA, Brazil.

Correspondence: Dr. Paulo Lisboa Bittencourt - Rua Prof. Clementino Fraga, 220 - apt. 1901 - Ondina - 40170-050 - Salvador, BA, Brasil. E-mail: plbbr@uol.com.br 
reversal of HRS-1 without relapse after treatment withdrawal was observed in approximately $60 \%-80 \%$ of the cases with an associated short-term survival of $30 \%$ to $45 \%$ in those treated patients $^{(1,2,8,9,17,18,19,21,22,23,29,31,24,33)}$. In addition, employment of transjugular intrahepatic portossystemic shunts (TIPS) in subjects with ascites and HRS-1 was also associated with good short-term outcomes ${ }^{(7,16)}$. These impressive findings led some authorities to recommend splancnic vasoconstrictors and high dose albumin as first-line therapy for HRS-1, leaving TIPS suitable for those subjects with HRS-1, without contraindications for the procedure, who fail or have intolerance to splancnic vasoconstrictors and high-dose albumin ${ }^{(12,27)}$.

Based on these results we have begun to institute treatment with terlipressin and high-dose albumin, using previously published schedules ${ }^{(31)}$, in subjects with CLD and clear-cut criteria for HRS-1 in the waiting list for liver transplantation. The purpose of the present study was to depict our results with the aforementioned treatment in the first seven patients submitted to therapy with terlipressin and high-dose albumin.

\section{METHODS}

Seven patients (median age 60 [47-69], five males) admitted to the Unit of Gastroenterology and Hepatology of the "Hospital Português" of Salvador, BA, Brazil due to decompensated CLD and HRS-1 that required treatment with terlipressin and high-dose albumin were retrospectively reviewed. This study was approved by the Ethics Committee of the "Hospital Português".

Decompensation of CLD was defined in every patient by the occurrence of variceal bleeding, hepatic encephalopathy, infections and tense ascites as well as any other acute clinical event requiring hospitalization in the intensive care unit (ICU). The diagnosis of CLD was based on clinical, biochemical and echographic findings, as well as on liver histology, whenever a liver biopsy specimen was available. In the case of more than one cause for admission, the main cause was reckoned based on the following hierarchy: upper digestive bleeding, infection, hepatic encephalopathy, tense ascites and others ${ }^{(12)}$.

Information regarding clinical and laboratory parameters were sought in each patient, including etiology and cause for CLD decompensation. Severity of CLD was assessed by the Child-Pugh classification ${ }^{(25)}$ and the MELD score ${ }^{(32)}$.

The diagnosis of HRS-1 in all patients was determined according to guidelines of the International Ascites Club ${ }^{(3)}$. Briefly, HRS-1 was suspected in all subjects based on the presence of creatinine levels greater than $1.4 \mathrm{mg} / \mathrm{mL}$ either at admission or during hospitalization doubling to levels higher than $2.5 \mathrm{mg} / \mathrm{mL}$ within 2 weeks in the absence of shock, hypovolemia, bacterial infections or known exposure to nephrotoxic agents or a recognizable etiology for chronic renal failure. Infections were sought in every patient at admission and whenever there was a clinical suspicion during hospitalization. In this respect, all subjects were submitted to urine analysis, urine culture, chest X-rays, as well as leukocyte counts and culture of ascitic fluid, in the presence of ascites. Criteria for the occurrence of infections included either culture-proven or clinically suspected bacterial infections requiring antibiotics.

Failure to attain creatinine levels under $1.4 \mathrm{mg} / \mathrm{mL} 24$ hours after volume expansion with at least $1500 \mathrm{~mL}$ of cristalloids or 72 hours after institution of antibiotics with apparent control of infection were indicative of the presence of HRS, that was confirmed after exclusion of possible causes of intrinsic renal diseases by 24-hour urine protein excretion levels lower than $500 \mathrm{mg} /$ day, as well as by the absence of renal parenchyma abnormalities at the ultrasound.

After establishment of the diagnosis of HRS-1 and prior to institution of therapy with terlipressin and albumin, all seven patients were submitted to central line and urinary catheter insertion as well as to non-invasive hemodynamic monitoring. Central venous pressure (CVP), arterial pressure, heart rate and urinary output were checked every 2 to 4 hours. An electrocardiogram was performed before treatment and thereafter whenever there was a clinical suspicion of myocardial ischemia.

Treatment was undertaken according to a pre-treatment defined protocol based on a previously published study ${ }^{(31)}$. Briefly, terlipressin was begun with a intravenous bolus dose of $0.5 \mathrm{mg}$ every 4 hours. After each 3 days of treatment, an increment in dosage of $0.5 \mathrm{mg}$ was instituted in the absence of reversal of renal failure until the maximum dose of 2 mg every 4 hours. Whenever HRS-1 reversal was obtained, a gradual reduction in dosage until interruption was performed in a period of 3 days. Albumin was administered intravenously at the dose of $1 \mathrm{mg} / \mathrm{kg} / \mathrm{day}$ in the first day of treatment followed by daily dosages, respectively, of $40 \mathrm{~g} /$ day and $30 \mathrm{~g} /$ day in the 2 nd to $3 \mathrm{rd}$ days and subsequently $20 \mathrm{~g} /$ day through the 5 th day until the end of treatment. Therapy was maintained for the maximum of 14 days. Albumin infusions were interrupted in the presence of CVP values above $18 \mathrm{~mm} \mathrm{Hg}$ and therapy was suspended whenever myocardial or peripheral vascular ischemia was suspected or documented. ICU.

Patients were followed until death or discharge from the

Outcomes were assigned as regression, stabilization or progression of renal failure based on comparison of creatinine levels at the diagnosis of renal failure and at hospital discharge or death. Regression was assumed in the occurrence of normalization of creatinine levels at discharge. In the absence of regression, three distinct intervals of creatinine levels were created for comparisons: under $2 \mathrm{mg} / \mathrm{mL}$; between 2-3 $\mathrm{mg} / \mathrm{dL}$ and above $3 \mathrm{mg} / \mathrm{mL}$. Stabilization was considered, in the absence of regression, whenever the creatinine level at discharge remains below or in the same interval of the creatinine level at the diagnosis of renal failure, whereas progression was considered whenever the creatinine levels at discharge remains above the interval of the creatinine at diagnosis of renal impairment.

\section{Statistical analysis}

Clinical data are presented in text and tables as median and range. 


\section{RESULTS}

Clinical and laboratory parameters of the patients are depicted in Table 1. Most of them had hepatitis $\mathrm{C}$ and alcoholic liver disease as etiology for CLD. The cause of hepatic decompensation at admission was either respiratory distress due to tense ascites $(n=3)$ or infections $(n=4)$. All subjects had end-stage CLD expressed by median MELD and Child-Pugh scores of 12 [10-15] and 22 [17-38], respectively.

All patients were submitted to therapy with terlipressin and albumin only after the diagnosis of HRS-1 with the aforementioned treatment schedule. The median duration of therapy was 5 [1-14] days. Baseline creatinine levels, total leukocyte counts and 24-hour urine output were, respectively, $2.9[2.3-4.0] \mathrm{mg} / \mathrm{mL} ; 10.600[3.900-16.800]$ cells $/ \mathrm{mm}^{3}$ and 600 [150-1.400] mL per 24-hour period. According to baseline parameters, five patients exhibited creatinine levels greater than $2.5 \mathrm{mg} / \mathrm{mL}$, four had leukocytosis and three patients had oliguria, expressed as urinary output lower than 400 $\mathrm{mL}$ per 24-hour period.

TABLE 1. Clinical and laboratory features of patients with HRS-1

\begin{tabular}{lc}
\hline Clinical and laboratory features & $\mathrm{n}=7$ \\
\hline Male sex & 5 \\
Mean age & $64[47-69]$ \\
Etiology of cirrhosis & \\
$\quad$ Alcoholic liver disease & 3 \\
$\quad$ Hepatitis C & 3 \\
$\quad$ Hereditary hemochromatosis & 1 \\
Causes of decompensation & 3 \\
$\quad$ Tense ascitis & 4 \\
$\quad$ Infections* & 3 \\
$\quad$ Urinary tract infection & 1 \\
$\quad$ Spontaneous bacteremia & 2 \\
$\quad$ Skin and soft tissue infections & $12[10-15]$ \\
Mean Child-Pugh score & $22[17-38]$ \\
Mean MELD score &
\end{tabular}

The results of treatment are depicted in Table 2. None of the patients exhibited reversion of HRS-1 with the aforementioned treatment schedule of terlipressin associated with high-dose albumin and all but two patients died during treatment due to sudden death $(\mathrm{n}=1)$, multiple organ dysfunction associated with end-stage liver failure $(n=2)$ and sepsis $(n=2)$. The two survivors had either stabilization $(\mathrm{n}=1)$ or progression $(n=1)$ and were discharged alive from the ICU.

\section{DISCUSSION}

In the present study, reversal of HRS-1 was observed in none of the patients submitted to treatment with terlipressin and high-dose albumin and all but two patients died during the treatment period. These findings are distinct from those observed in previous pilot studies that reported reversal of HRS-1 in $62 \%$ of the patients treated with high-dose albumin and different splancnic vasoconstrictors, including terlipressin, as well as an overall survival rate of $42 \%$ and $30 \% 1$ and
TABLE 2. Clinical and laboratory parameters of the patients with HRS-1 treated with terlipressin and albumin

\begin{tabular}{cccccccc}
\hline Patient & Age & CPS & MELD & $\begin{array}{c}\text { Pre-treatment } \\
\text { creatinine } \\
\text { levels }\end{array}$ & $\begin{array}{c}\text { Duration of } \\
\text { treatment }\end{array}$ & $\begin{array}{c}\text { Creatinine } \\
\text { at the last } \\
\text { FU }\end{array}$ & $\begin{array}{c}\text { Cause of } \\
\text { death }\end{array}$ \\
\hline 1 & 66 & 12 & 34 & 2,3 & 7 & 4,1 & $\begin{array}{c}\text { Septic } \\
\text { shock }\end{array}$ \\
2 & 56 & 13 & 38 & 3,6 & 1 & 3,6 & $\begin{array}{c}\text { Sudden } \\
\text { death }\end{array}$ \\
3 & 64 & 10 & 17 & 2,6 & 5 & 3,4 & $\begin{array}{c}\text { Hepatic } \\
\text { failure }\end{array}$ \\
4 & 47 & 10 & 18 & 2,9 & 14 & 1,6 & - \\
5 & 48 & 15 & 25 & 2,9 & 14 & 4,1 & - \\
6 & 69 & 17 & 21 & 4 & 5 & 4,4 & $\begin{array}{c}\text { Hepatic } \\
\text { failure }\end{array}$ \\
7 & 68 & 10 & 22 & 2,8 & 2 & 5,2 & $\begin{array}{c}\text { Septic } \\
\text { shock }\end{array}$ \\
\hline
\end{tabular}

3 months after treatment, respectively ${ }^{(6)}$. Worse outcomes were nevertheless reported from two recent randomized controlled trials that included 112 and 46 patients with HRS-1, respectively, from North-America and Northern Europe $^{(28)}$ and from Spain ${ }^{(20)}$. SANYAL et al. ${ }^{(28)}$ reported HRS-1 reversal in only $34 \%$ of those patients treated with terlipressin and high-dose albumin. However, only $13 \%$ of their patients submitted to placebo and albumin achieved reversal of renal failure. Even though the difference in the frequency of HRS-1 reversal was significant between the two treatment arms, no significant impact on overall survival was observed. Likewise, MARTIN-LLAHI et al. ${ }^{(20)}$ from the Barcelona group described a significant improvement of renal function in patients treated with terlipressin and high-dose albumin $(44 \%)$ when compared to those treated only with high-dose albumin $(9 \%)$, with no effect in overall and transplantationfree survival. Independent baseline parameters associated with treatment response were baseline urine volume, serum creatinine and leukocyte count. In this regard, subjects with oliguria, higher creatinine levels and leukocytosis, probably reflecting uncontrolled infection, before institution of therapy with terlipressin and high-dose albumin were less likely to respond to treatment ${ }^{(20)}$. Mortality at 3 months in this trial was further associated with baseline MELD score and lack of improvement of renal function ${ }^{(20)}$.

Altogether, the results of these two randomized controlled $\operatorname{trials}^{(6,22)}$ were less impressive, when compared to previously published pilot studies, but were far better than those observed in the present series of patients, where reversal of HRS-1 was obtained in none of the treated subjects and all but two patients died while in the ICU.

There are however major issues that had to be highlighted in order to understand our adverse results. First of all, it has to be stressed that most of our patients had baseline features previously associated with adverse outcomes, particularly high MELD scores and creatinine levels, low urine volume and leukocytosis, possibly reflecting uncontrolled infection ${ }^{(20,28)}$. 
On the other hand, the institution of therapy was delayed in most of our patients that had HRS-1 induced by infection, due to the fact that infection had to be entirely ruled out or controlled to meet current criteria for the diagnosis of HRS-1, based on guidelines of the International Ascites Club published on $1996^{(3)}$. These criteria for the diagnosis of HRS-1 have been recently revised particularly to encompass renal failure occurring as a complication of ongoing bacterial infection, in the absence of septic shock, and it is now not recommended to withhold treatment, until infection is adequately treated ${ }^{(27)}$. Another major issue that could be implicated as one of the reasons for our bad results was the initial low dose of terlipressin $(0.5 \mathrm{mg}$ each 4 hours for the first 3 days) that was employed in our patients, which was lower than the dose employed in those two randomized trials, as well as in some pilot studies ${ }^{(6,20,28)}$. The terlipressin dose and schedule was chosen based on a published study from the group of Barcelona ${ }^{(31)}$ as well as due to safety reasons. Adverse events are not uncommon with the use of terlipressin, particularly in those patients with advanced CLD. MARTINLLAHI et al. ${ }^{(20)}$ have reported cardiovascular complications in $43 \%$ of the patients treated with terlipressin and albumin, leading to terlipressin withdrawal in $13 \%$ of the subjects, whereas SANYAL et al ${ }^{(28)}$ have described one non-fatal acute myocardial infarction related to terlipressin administration. We had also one patient that had sudden death in the first 24 hours after terlipressin use, which could be viewed as a drug-related fatal adverse event.

In summary, none of the patients with HRS- 1 treated with terlipressin and albumin had reversal of renal failure. Most had adverse prognostic factors associated with non-response as well as delayed treatment institution and all were treated with doses of terlipressin nowadays considered suboptimal for treatment of HRS-1.

Despite our poor results in view of the aforementioned data, we still recommend treatment of HRS-1 with terlipressin and high-dose albumin taking into consideration some important points: early administration of therapy; employment of proper doses of terlipressin; avoidance of candidates that are too sick for treatment and not amenable to proceed further for liver transplantation and treatment institution preferably in the ICU setting.

Kalil JR, Cerqueira LA, Barbosa DS, Motta MP, Nery MS, Bittencourt PL. Resultados adversos com o emprego de vasoconstritores esplâncnicos e albumina para tratamento da síndrome hepatorrenal do tipo 1: relato de sete casos e revisão da literatura. Arq Gastroenterol. 2009;46(3):214-8.

RESUMO - Contexto - O tratamento da síndrome hepatorrenal do tipo 1 (SHR-1) com vasoconstritores esplâncnicos e albumina intravenosa tem se associado, em relatos de caso e estudos piloto não-controlados, à reversão da insuficiência renal em $60 \%-80 \%$ dos pacientes tratados. Objetivo Avaliar os resultados do tratamento da SHR-1 com terlipressina e albumina. Métodos - Foram avaliados, retrospectivamente, todos os pacientes hospitalizados com o diagnóstico de SHR-1 que se submeteram a tratamento com terlipressina associada à albumina em altas doses. As frequências de reversão de insuficiência renal e óbito foram comparados com parâmetros clínicos e laboratoriais pré-tratamento. Resultados - Sete pacientes (5 homens, idade mediana 64 [47-69] anos) com mediana de pontuação Child-Pugh e MELD respectivamente de 12 [10-15] e 22 [17-38], admitidos na unidade de terapia intensiva por desconforto respiratório secundário à ascite tensa ou por infecções, que apresentaram critérios para SHR-1 e eligibilidade para o transplante de fígado foram submetidos a tratamento com terlipressina e albumina, de acordo com protocolo pré-definido. Níveis de creatinina prévios ao tratamento foram de 2.9 [2.3-4.0] mg/mL. Nenhum paciente apresentou reversão da SHR-1 e cinco faleceram por morte súbita $(n=1)$, disfunção de múltiplos órgãos associada a falência hepática $(n=2)$ e sepse $(n=2)$, a maioria antes de completar o tratamento. Conclusões - O tratamento da SHR-1 com terlipressina e albumina, em altas doses, não foi associado à reversão da insuficiência renal em nenhum dos pacientes tratados, mas a maioria dos pacientes apresentava doença hepática em fase avançada, com altos valores de MELD, e níveis elevados de creatinina pré-tratamento, parâmetros previamente associados com pior resposta e prognóstico mais reservado.

DESCRITORES - Síndrome hepatorrenal. Hepatopatias. Vasoconstritores. Albuminas. 


\section{REFERENCES}

1. Alessandria C, Ottobrelli A, Debernardi-Venon W, Todros L, Cerenzia MT, Martini S, Balzola F, Morgando A, Rizzetto M, Marzano A. Noradrenalin vs terlipressin in patients with hepatorenal syndrome: a prospective, randomized, unblinded, pilot study. J Hepatol. 2007;47:499-505.

2. Angeli P, Volpin R, Gerunda G, Craighero R, Roner P, Merenda R, Amodio P, Sticca A, Caregaro L, Maffei-Faccioli A, Gatta A. Reversal of type 1 hepatorenal syndrome with the administration of midodrine and octreotide. Hepatology. 1999;29:1690-7.

3. Arroyo V, Ginès P, Gerbes AL, Dudley FJ, Gentilini P, Laffi G, Reynolds TB, Ring-Larsen H, Schölmerich J. Definition and diagnostic criteria of refractory ascites and hepatorenal syndrome in cirrhosis. Hepatology. 1996;23:164-76.

4. Arroyo V, Colmenero J. Ascites and hepatorenal syndrome in cirrhosis: pathophysiological basis of therapy and current management. J Hepatol. 2003;38(suppl.1):s69-s89.

5. Arroyo V, Terra $C$, Ginès $P$. New treatments of hepatorenal syndrome. Semin Liver Dis. 2006;26:254-64.

6. Arroyo V, Terra C, Ginès P. Advances in the pathogenesis and treatment of type-1 and type-2 hepatorenal syndrome. J Hepatol. 2007;46:935-46.

7. Brensing KA, Textor J, Perz J, Schiedermaier P, Raab P, Strunk H, Klehr HU, Kramer HJ, Spengler U, Schild H, Sauerbruch T. Long term outcome after transjugular intrahepatic portosystemic stent-shunt in non-transplant cirrhotics with hepatorenal syndrome: a phase II study. Gut. 2000;47:288-95.

8. Colle I, Durand F, Pessione F, Rassiat E, Bernuau J, Barrière E, Lebrec D, Valla DC, Moreau R. Clinical course, predictive factors and prognosis in patients with cirrhosis and type-1 hepatorenal syndrome treated with terlipressin: a retrospective analysis. J Gastroenterol Hepatol. 2002;17:882-8.

9. Duvoux C, Zanditenas D, Hézode C, Chauvat A, Monin JL, Roudot-Thoraval F, Mallat A, Dhumeaux D. Effects of noradrenalin and albumin in patients with type 1 hepatorenal syndrome: a pilot study. Hepatology. 2002;36:374-80.

10. Fabrizi F, Dixit V, Martin P. Meta-analysis: terlipressin therapy for the hepatorenal syndrome. Aliment Pharmacol Ther. 2006;24:935-44.

11. Fasolato S, Angeli P, Dallagnese L, Maresio G, Zola E, Mazza E, Salinas F, Donà S, Fagiuoli S, Sticca A, Zanus G, Cillo U, Frasson I, Destro C, Gatta A. Renal failure and bacterial infections in patients with cirrhosis: epidemiology and clinical features. Hepatology. 2007;45:223-9.

12. Fernández J, Navasa M, Gómez J, Colmenero J, Vila J, Arroyo V, Rodés J. Bacterial infections in cirrhosis: epidemiological changes with invasive procedures and norfloxacin prophylaxis. Hepatology. 2002;35:140-8

13. Follo A, Llovet JM, Navasa M, Planas R, Forns X, Francitorra A, Rimola A, Gassull MA, Arroyo V, Rodés J. Renal impairment after spontaneous bacterial peritonitis in cirrhosis: incidence, clinical course, predictive factors and prognosis. Hepatology. 1994;20:1495-501.

14. Ginès A, Escorsell A, Ginès P, Saló J, Jiménez W, Inglada L, Navasa M, Clària J, Rimola A, Arroyo V, et al. Incidence, predictive factors, and prognosis of hepatorenal syndrome in cirrhosis with ascites. Gastroenterology. 1993;105: 229-36.

15. Ginès $\mathrm{P}$, Guevara $\mathrm{M}$, Arroyo V, Rodés J. Hepatorenal syndrome. Lancet. 2003;362:1819-27.

16. Guevara M, Ginès P, Bandi JC, Gilabert R, Sort P, Jiménez W, Garcia-Pagan JC, Bosch J, Arroyo V, Rodés J. Transjugular intrahepatic portosystemic shunt in hepatorenal syndrome: effects on renal function and vasoactive systems. Hepatology. 1998;28:416-22.

17. Guevara M, Ginès P, Fernández-Esparrach G, Sort P, Salmerón JM, Jiménez W, Arroyo V, Rodés J.. Reversibility of hepatorenal syndrome by prolonged administration of ornipressin and plasma volume expansion. Hepatology. 1998;27:35-41.
18. Gülberg V, Bilzer M, Gerbes AL. Long-term therapy and retreatment of hepatorenal syndrome type 1 with ornipressin and dopamine. Hepatology. 1999;30:870-5.

19. Halimi C, Bonnard P, Bernard B, Mathurin P, Mofredj A, di Martino V, Demontis R, Henry-Biabaud E, Fievet P, Opolon P, Poynard T, Cadranel JF. Effect of terlipressin (Glypressin) on hepatorenal syndrome in cirrhotic patients: results of a multicentre pilot study. Eur J Gastroenterol Hepatol. 2002;14:153-8.

20. Martín-Llahí M, Pépin MN, Guevara M, Díaz F, Torre A, Monescillo A, Soriano G, Terra C, Fábrega E, Arroyo V, Rodés J, Ginès P; TAHRS Investigators. Terlipressin and albumin vs albumin in patients with cirrhosis and hepatorenal syndrome: a randomized study. Gastroenterology. 2008;134:1352-9.

21. Moreau R, Durand F, Poynard T, Duhamel C, Cervoni JP, Ichaï P, Abergel A, Halimi C, Pauwels M, Bronowicki JP, Giostra E, Fleurot C, Gurnot D, Noue O, Renard P, Rivoal M, Blanc P, Coumaros D, Ducloux S, Levy S, Pariente A, Perarnau JM, Roche J, Scribe-Outtas M, Valla D, Bernard B, Samuel D, Butel J, Hadengue A, Platek A, Lebrec D, Cadranel JF. Terlipressin in patients with cirrhosis and type 1 hepatorenal syndrome: a retrospective multicenter study. Gastroenterology.2002;122:923-30.

22. Mulkay JP, Louis H, Donckier V, Bourgeois N, Adler M, Deviere J, Le Moine O. Long-term terlipressin administration improves renal function in cirrhotic patients with type 1 hepatorenal syndrome: a pilot study. Acta Gastroenterol Belg. 2001;64:15-9.

23. Neri S, Pulvirenti D, Malaguarnera M, Cosimo BM, Bertino G, Ignaccolo L, Siringo S, Castellino P. Terlipressin and albumin in patients with cirrhosis and type I hepatorenal syndrome. Dig Dis Sci. 2008;53:830-5.

24. Ortega R, Ginès P, Uriz J, Cárdenas A, Calahorra B, De Las Heras D, Guevara M, Bataller R, Jiménez W, Arroyo V, Rodés J. Terlipressin therapy with and without albumin for patients with hepatorenal syndrome: results of a prospective nonrandomized study. Hepatology. 2002;36:941-8.

25. Pugh RN, Murray-Lyon IM, Dawson JL, Pietroni MC, Williams R. Transection of the oesophagus for bleeding oesophageal varices. Br J Surg. 1973;60:646-9.

26. Ruiz-del-Arbol L, Monescillo A, Arocena C, Valer P, Ginès P, Moreira V, Milicua JM, Jiménez W, Arroyo V. Circulatory function and hepatorenal syndrome in cirrhosis. Hepatology. 2005;42:439-47.

27. Salerno F, Gerbes A, Ginès P, Wong F, Arroyo V. Diagnosis, prevention and treatment of hepatorenal syndrome in cirrhosis. Gut. 2007;56:1310-8.

28. Sanyal AJ, Boyer T, Garcia-Tsao G, Regenstein F, Rossaro L, Appenrodt B, Blei A, Gülberg V, Sigal S, Teuber P; Terlipressin Study Group. A randomized, prospective, double-blind, placebo-controlled trial of terlipressin for type 1 hepatorenal syndrome. Gastroenterology. 2008;134:1360-8.

29. Solanki P, Chawla A, Garg R, Gupta R, Jain M, Sarin SK. Beneficial effects of terlipressin in hepatorenal syndrome: a prospective, randomized placebo-controlled clinical trial. J Gastroenterol Hepatol. 2003;18:152-6.

30. Terra C, Guevara M, Torre A, Gilabert R, Fernández J, Martín-Llahí M, Baccaro ME, Navasa M, Bru C, Arroyo V, Rodés J, Ginès P. Renal failure in patients with cirrhosis and sepsis unrelated to spontaneous bacterial peritonitis: value of MELD score. Gastroenterology. 2005;129:1944-53.

31. Uriz J, Ginès P, Cárdenas A, Sort P, Jiménez W, Salmerón JM, Bataller R, Mas A, Navasa M, Arroyo V, Rodés J. Terlipressin plus albumin infusion: an effective and safe therapy of hepatorenal syndrome. J Hepatol. 2000;33:43-8.

32. Wiesner R, Edwards E, Freeman R, Harper A, Kim R, Kamath P, Kremers W, Lake J, Howard T, Merion RM, Wolfe RA, Krom R; United Network for Organ Sharing Liver Disease Severity Score Committee. Model for end-stage liver disease (MELD) and allocation of donor livers. Gastroenterology. 2003;124:91-6.

33. Wong F, Pantea L, Sniderman K. Midodrine, octreotide, albumin, and TIPS in selected patients with cirrhosis and type 1 hepatorenal syndrome. Hepatology. 2004; $40: 55-64$

Recebido em 25/8/2008 Aprovado em 2/2/2009. 